\title{
Managerial Ability and Internal Control Quality: Evidence from China
}

\author{
$\mathrm{Han} \mathrm{Li}^{1}$ \\ ${ }^{1}$ SILC Business School, Shanghai University, Shanghai, China \\ Correspondence: Han Li, SILC Business School, Shanghai University, 20 Chengzhong Road, JiaDing District, \\ Shanghai 201800, China. Tel: 86-21-6998-0028 ext. 53101. E-mail: lihan@shu.edu.cn
}

Received: February 11, 2015

Accepted: March 2, 2015

Online Published: March 23, 2015

doi:10.5430/ijfr.v6n2p54

URL: http://dx.doi.org/10.5430/ijfr.v6n2p54

\begin{abstract}
Internal control quality of the firms can be determined by the firms' specific features, auditing quality and corporate governance. This research tries to make sure another factor-managerial ability is positively associated with internal control quality. With the evidences based on the A share in China's capital markets from 2009 to 2012, this research testifies that this relationship is statistically significant. Disclosing the internal control quality for all listed firms in China are mandatory since 2012. The research also exams how managerial ability has the different impacts on internal control quality within the voluntary disclosing periods and within the mandatory disclosing periods. It is found that the impact of managerial ability on internal control quality decreased in statistics.
\end{abstract}

Keywords: top executives, managerial ability, managerial efficiency, internal control quality, internal control weaknesses

\section{Introduction}

Since the beginning of $21^{\text {st }}$ century, many financial scandals, such as Enron, WorldCom, etc., made how to protect shareholders' wealth become an interesting and challenging research issues. Many researches focus on earnings management and corporate governance. Furthermore, many researches argue that it is internal control that matters with earnings quality and corporate governance. Some scholars find that the firm size, business complexity, financial risk, internal and external auditing quality and corporate governance would determine the internal control quality. Top executives as policy makers and firm's authority play very important roles on internal control. It is found that CEO demographic characteristics (tenure, age, gender, etc.) matters for internal control quality (hereafter abbreviated as ICQ) and top management's equity incentives relate to the ICQ as well (Lin et al., 2014; Balsam et al., 2014). Although top executives desire to have a better internal control quality to meet the performance required by equity incentives scheme, how efficient and effective top executives design and implement the internal control is unclear. This research argues that managerial ability, especially the top executives' ability is positively related with the internal control quality.

After the enactment of SOX 302 and SOX 404 in US that requires the top executives take responsibilities on the internal control and the disclosing of the internal control becomes mandatory, many countries' financial reporting regulations have similar internal control information disclosure requirements. In 2012, all listed firms in China should disclose their internal control reports. There are some arguments against the disclosure of internal control information because large amounts of cost would arise simply due to the new disclosing policy. However, many researches also find that better internal control quality would reduce the cost of capital and earnings manipulation, increase the firm's reputation and accrual quality and the firm's value. Prior research mainly analyzes the drivers to the internal control quality in the company's level through the following aspects :(1) the firm's characteristics, such as firm size and firm age; (2) the complexity of business activities, such as more business segments, foreign transactions; (3) financial reporting risk, such as loss proportion, sales growth; (4) the internal control environment, such as auditor quality; (5) corporate governance, such as the Board of Directors size. This research is in the vein of these thoughts to investigate the relationship between managerial ability and internal control quality.

Managerial ability is one of the factors to drive for the firm's operating efficiency. In this research, managerial ability is defined as the top executives' ability. There are two proxies for the managerial ability. One is managerial score (MgrlScore), the other is the managerial compensation (MgrlComp). First, the managerial score is the residual value of the firm's efficiency regression model. In this research, the firm's efficiency is measured as the sales divided by 
the operating costs including costs of goods sold (COGS), selling expense, financing expense, administration expense, research and development, goodwill and other intangible assets. The DEA (Data Envelopment Analysis) is applied to find an optimal firm's efficiency data. In order to determine the managerial ability, a regression model is designed. The dependent variable is firm's optimal efficiency. While, the independent variables are including firm size, firm age, market share, business complexity, foreign translation and etc. In China, managerial power plays significant roles on the firm's efficiency. Managerial power is also added into the regression model as an independent variable. The residual value is the required managerial ability (MgrlScore). Secondly, the managerial ability is based on the top management's compensation because there is significant relationship between top management's compensation and firm's efficiency. Top executives with higher managerial ability normally are rewarded higher compensation.

The purposes of internal controls are to guarantee the firm's strategy and objectives can be successfully reached. With the business development of firms, the firm's size and business procedure are increasing significantly. The financial reporting becomes the main basis for management decisions. Better internal control system would lead to better financial reporting quality. According to the $1992 \mathrm{COSO}$ model, the internal controls are assessed by the following elements:(a) the control environment; (b) risk assessment; (c) control activities; (d) information and communication; (e) monitoring. In this research, the internal control is derived from the DIB database which published annually by DIB firm in China. The DIB index is a composite index in which the specific COSO 5 internal control elements are evaluated. The DIB index is the dependent variable to measure the internal control quality. Meanwhile, the managerial score (MgrlScore) and the managerial compensation (MgrlComp) are defined as the test variable respectively. The managerial scores (MgrlScore) are derived from the DEA (Data Envelopment Analysis) to measure the top executives' ability. The managerial compensation (MgrlComp) is the total of top 3 executives' compensation.

With two regression models analysis, this research convinces that there is a statistically significant relationship between managerial ability and internal control quality over the financial reporting based on the evidences in China's capital markets. The panel data is from 2009 to 2012. However, it is admitted that the potential endogeneity would exist due to the institutional environment factors.

This research makes some contributions to the accounting theories and professional practices. First, although previous researches investigated more the relationship among the CEO's demographic features and internal control quality, we are still not very clear about the association between the CEO's managerial ability and internal control quality. This research tries to fill this gap. Second, based on the updated financial information of Chinese capital markets, this research finds the evidence whether voluntary or mandatory internal control quality disclosure requirements have different impacts on the internal control quality. Finally, this research results would benefit for the firms' Board of Directors because the Board of Directors can find a new indicator (managerial ability) in order to improve the internal control quality. Similarly, the results could also give some valuable implications for the auditors to assess the firms' internal control quality.

This research is organized as follows: next part is the summary of prior research and the hypothesis development. Part 3 is the descriptions of the applied research methods. Part 4 is the research result analysis. Part 5 is the additional analysis. Summary is the last section.

\section{Literature Review and Hypothesis Development}

\subsection{Prior Research on Internal Control Quality}

The Sarbanes-Oxley Act (SOX) which is approved by US Congress in 2002 required the firms listed in US capital markets to disclose their management's assessment on internal control (SOX Section 404) and the CEOs and CFOs to evaluate and report their firms' internal control (SOX Section 302). Since then, lots of research papers focus on the internal control quality of firms and to compare the costs with the benefits after the implementation of Section 404 and Section 302 in SOX act. It is very clear that these researches can be classified into two streams: one direction is to investigate the effectiveness of internal control, and the other is to find what factors drive to the increase of internal control quality in firms.

The disclosure of management's assessment on internal control quality leads to several consequences which benefit the increase of shareholders' value. Dechow et al. (1995) evaluated a modified Jones (1991) models in detecting earnings management. With the modified Jones models, Dechow and Dichev (2002) testified that accrual quality systematically relates to observable firm and industry characteristics. While, the Internal control quality (ICQ) is one of key firm and industry characteristics. It plays an important role on the accrual quality (Doyle, et al., 2007 a; Ashbaugh et al., 2008). Secondly, another effect on internal control is cost of capital. Higher internal control 
weaknesses (hereafter ICWs) that also mean lower internal control quality are associated with higher cost of bank loan (Kim et al., 2011). Also ICWs lead to higher implied cost of equity (Ogneva et al., 2007). Third, the high frequency of disclosing of internal control weaknesses (ICWs) reflects the management teams have strong willingness to strengthen the quality of internal control. Therefore, these activities would significantly improve the investment efficiency (Cheng et al., 2013). Finally, there are other economic impacts on the disclosure of the internal control weaknesses, such as, higher audit risk and audit fees (Hoitash et al., 2008), less accurate internal management guidance (Feng et al., 2009), lower conditional conservatism (Goh and $\mathrm{Li}, 2011$ ), negative change on CFO's compensation (Hoitash et al., 2012), greater probability of inside trading (Ashbaugh et al.,2013). It is obvious that better internal control quality for the listed firms would decrease the above financial, audit and operational risk and increase the shareholder's value.

Unlike some researches emphasize the various effects on the internal control of firms, some try to investigate what the factors determine the internal control quality. First, ICQ is driven by firm's specific features. Internal control quality has associated with the firm size, firm age and firm's resources in supporting of internal controls; Moreover, ICQ is influenced by the complexity of business operations. Firms which involved with many business segments have higher probability in disclosure of internal control weaknesses. Foreign exchange transactions among firms easily lead to internal control deficiencies and worsen internal control quality; Furthermore, ICQ is determined by the firm's financial reporting risks which could be arisen due to the complicated financial reporting procedures, restructuring the firm's organization, severe financial condition and weak corporate governance. ICQ also has related with firms outside factors, such as higher quality of auditing, more auditor resignations, and more financial reports restatements. The corporate governance can also influence the internal control quality as well. (Doyle et al., $2007 \mathrm{~b}$; Ashbaugh-Skaife et al., 2007; Tian et al., 2010).

In the prior archival research literature, no conclusion is made for explaining the relationship between managerial ability and internal control quality. This research is to make up the gap. Prior research finds that management team characteristics, also named as management fixed effects or managerial styles, really matter for the firm's financing, investment and organization performance (Bertrand and Schoar, 2003). Moreover, top manager's personal demographic features influence the voluntary disclosure styles (Bamber et al., 2010). Demerjian et al. (2013) argues that higher managerial ability for top executives is associated with better the earning quality. Furthermore, CEOs personal characteristics matters for the internal control quality. Higher percent share ownership, longer tenure and younger age for top executives increase the disclosure of internal control material weaknesses (Lin et al., 2014). This research would be in the vein of the researches which find significant association between top executives' demographic features and internal control quality. It tries to find the evidences that managerial ability has related to the internal control quality.

\subsection{Research on Internal Control Quality in China}

With the development of capital markets in China, the numbers of financial fraud scandals are increasing. In order to protect the interests of shareholder and avoid the leaking of state owned assets, the Ministry of Finance and other 4 governmental departments issued "The Basic Standard of Enterprise Internal Control" (hereafter abbreviated as Basic Standard). The Basic Standard in China follows the main principles adopted in US SOX act. After the China's SOX (the Basic Standard) enacted, other three internal control guidelines were published in 2010. All listed firms in China should mandatorily report their internal control assessment results since 2012 (Ji et al., 2014).

Similar as the previous discussed researches of internal control which are testified by the data mainly in developed countries, many researches about internal control in China investigate the economic consequences and determinants of internal control. In China, higher internal control quality could improve the earnings quality (Xiao and Zhang, 2013; Ye et al., 2012), lower the cost of debt (Chen et al., 2014), increase investment efficiency (Li et al., 2011), increase sensitivity in the executives' remuneration ( $\mathrm{Lu}$ et al., 2011), etc. Meanwhile, factors on internal control quality are including: firm specific characteristics, complexity of business activities, financial reporting risk, auditing quality, corporate governance and institutional environmental factors (Tian et al., 2010; Liu et al., 2012; Ji et al., 2014).

\subsection{Hypothesis Development}

The Committee of Sponsoring Organizations of the Treadway Commission (COSO) designed a guidance and framework to assess an internal control system in firms. In COSO's internal control framework, there are 5 major indicators: control environment, risk assessment, communication and information, monitoring and control activities (Tsay, 2010). However, the top management is obviously the ultimate driver to achieve the above 5 indicators. Management's commitment about the design and implementation of effective internal control system and the reduction of internal control material weaknesses is a necessary foundation to build up a better control environment. 
However, top management's attitude on the implementation of internal control system is hard to observe and measure. Management's tone on internal control system, for example, public announcement and documented policies, can be used as an alternative method to measure the top manager's commitment on internal control quality (Tsay, 2010).Besides the tone on top management, whether the top management executes the commitments and policies on the internal control in an efficient and effective way or not is also important. Therefore, management efficiency should be measured to assess the internal control system. Management efficiency measure how much sales revenues would have got based on the given operating costs. Many factors can influence the management efficiency, such as macroeconomic conditions, firm's size, firm's age, free cash flows, foreign exchange activities and managerial ability. In short, managerial ability, one of factors which have impacts on management efficiency, determines the efficiency and effectiveness of executing internal control system.

Higher managerial ability leads to higher sales revenues based on the given costs, then higher profit of the firms. Top executives with higher managerial ability has motivation to transfer these information to shareholders and other stakeholders in order to receive higher compensation. According to the signal theory, to design and implement a better internal control system and reduce the disclosure of material weaknesses about internal control system would distinguish these higher ability managers with other managers.

Furthermore, frequent disclosure of material weaknesses in the internal control would damage the top executives' reputation. It is known that better manager's reputation is in line of lower cost of capital for the firm and easily improve the manager's compensation in the manager's employment market. Higher ability managers desire to increase internal control quality for their employment reputation.

In sum, higher managerial ability managers prefer to increase the internal control quality. This research makes the following hypothesis:

Hypothesis: Managerial ability is positively associated with internal control quality.

\section{Method}

This research is in the vein of prior research about the determinants of internal control weaknesses. Top management should have strong managerial ability to build up higher internal control quality. All data originate from the China's capital markets. The descriptive analysis, correlation analysis and regression analysis are applied.

\subsection{Data and Sample Selection Procedure}

This research collects 2,510 firm samples in CSMAR database between 2009 and 2012. Because the structure of financial statements in financial industries is quite different with other sector's firms. This research deleted the firms which belong into commercial banks, insurance companies and investment banks. Then there are 2,457 firm samples which are non-financial industry's firms. In China's capital markets, B Share's par values are denominated in RMB currency and its trading is valued at foreign currency. B Share firms are financed by overseas institution investors. Obviously B Share is quite different with A share. B Share ID information are collected from the database operated by RoyalFlush Information Network (See Note 1). All B Share firms are further deducted. ST firms always face serious financial problems. Therefore, ST firms are not considered in this research. Moreover, 884 firms which exist missing data are deleted. Finally, there are 1,502 firm samples in this research.

Table 1. Sample selection

$\begin{array}{llr}\text { Sample } & & \\ \text { Total firms listed in Shanghai and Shenzhen stock markets } & 2510 \\ \text { less } & \text { Commercial Banks } & 16 \\ & \text { Insurance Companies } & 16 \\ & \text { Investment Banks } & 21 \\ \text { less } & \text { B Share Firms } & 2457 \\ & & 18 \\ \text { less } & \text { ST Firms } & 2439 \\ & & 53 \\ \text { less } & \text { Firms with missing data } & 2386 \\ & & \\ & & 1502\end{array}$




\subsection{Dependent Variable}

\subsubsection{Internal Control Quality}

There are mainly two internal control quality index in China. One is conducted by the research group in Xiamen University, the other is by DIB Enterprise Risk Management Technology Co., Ltd. In this research, DIB internal control index is applied to measure the internal control quality. According to the product description of DIB index, this index is the composite index which reflects the internal control information based on the listed firm's internal control disclosure reports, internal control assessment reports and auditing/assurance reports. The DIB index is published annually. The time period for measuring firm's internal control is from 2009 to 2012.

\subsection{Test Variable}

\subsubsection{Managerial ability}

In this research managerial ability is defined as the top executives' efficiency in firm's operating activities. Management's efficiency measures how many outputs are produced on the basis of the inputs in the firm. Management's efficiency is one of factors in determining the firm's operating efficiency. Firm efficiency is measured by the sales comparing with various costs and expenses. This research applies the Demerjian et al. (2013) method to measure the firm's efficiency by the Data Envelopment Analysis (abbreviated as DEA). The firm's efficiency can be solved as follows:

$$
\begin{aligned}
& \max _{v} \theta \\
& =\frac{\text { Sales }}{v_{1} \text { CoGS }+v_{2} \text { SellingExp }+v_{3} \text { FinExp }+v_{4} \text { AdminExp }+v_{5} P P E+v_{6} R \& D+v_{7} \text { Goodwills }+v_{8} \text { Intangible }}
\end{aligned}
$$

There are some adjustments in the above equation due to the availability of data information and accounting terms in China's accounting standards. The period expenses include selling Expenses (SelligExp), Finance Expenses (FinExp) and Administration Expenses (AdminExp). Unlike the research of Demerjian et al (2013), operating leases are not included in the above firm's efficiency equation. The DEA analysis is conducted by the software DEAP 2.1 (See Note 2). With the DEA analysis, firm efficiency is valued from 0 to 1 . There are lots of factors influencing the firm efficiency, such as firm's size, market capitalization size, free cash flow, business segments and organizational structure, foreign business activities and management power.

Daily et al. (1997) addressed that the management powers plays significant role in firm's financial performance (Daily et al., 1997). Management power as a new variable in the firm efficiency model. This is different with the method for evaluating firm's efficiency in the research of Demerjian et al. (2013).Management power has large impacts on strategic and operational decisions. Power can be measured by four dimensions: structural power, ownership power, expert power and prestige power (Finkelstein, 1992). In this research, managerial power is defined as the top executive's power. The Power variable is determined by (a) whether CEO is also the Chairman in Board of Directors ;(b) Board of Directors size; (c) the proportion of top executives holding share occupied by the total management team holding share. If CEO is entitled as the Chairman of BoDs, it means CEO has much powerful influence on firm's strategy and operational decisions. Second, if there are many directors in BoDs, power of the CEO and other top executives would be limited by large numbers of directors. It would be more difficult for top executives to make decisions without considering other directors' viewpoints. Therefore, large size of BoDs would reduce the power of top executives. Finally, it is obviously that the higher proportion of holding the firm's shares for top executives would reflect higher power in management.

Using the following aggression model, managerial ability is measured by the residual value $\varepsilon$.

$$
\begin{gathered}
\text { Firm Efficiency }=\alpha_{0}+\alpha_{1} \operatorname{Ln}(\text { Total Assets })+\alpha_{2} \text { Market Share }+ \\
\alpha_{3} \text { Positive Free Cash Flow }+\alpha_{4} \operatorname{Ln}(\text { Age })+\alpha_{5} \text { Business Complexity }+ \\
\alpha_{6} \text { Foreign Currency Indicator }+\alpha_{6} \text { Power }+ \text { Year Indicators }+\varepsilon
\end{gathered}
$$

\subsubsection{Managerial Compensation}

According to the Agency Theory, the ownership and the management are separated in order to effectively allocate the capital and technology (management skill) resources. The Board of Directors (BODs) in the firms evaluates the top executives' performance based on the financial and non-financial indicators. In modern business world, better performance originated from the stronger top executives would be rewarded much. Therefore, another variable to measure the managerial ability is the managerial compensation. The managerial compensation is selected based on the top 3 executives' compensation in CSMAR database. 


\subsection{Control Variable}

Based on prior research about the factors on internal control quality, this research sets up the following control variables. (a) Firm Characteristics. Firm size and firm age relate to internal control quality. Larger size firms always have better internal control quality than small ones; Younger firms always disclose more internal control deficiencies. (b) Complexity of Business Activities. If the firms have involved with more market capitalization, business segments, existence of mergers and acquisition and foreign transactions, the business procedures become more complex. The complicated business operations increase the possibility of deficiency in internal control system and reduced the internal control quality. (c) Financial Reporting Risk. This research applies loss proportion, sales growth and sales volatility as the measurement indicators of financial risk. Higher sales volatility makes the firms' financial situations more uncertain in future. Meanwhile, higher loss ratio which means worse financial performance and higher sales growth which indicates the rapid increase on sales imply that the firms are in the abnormal times. All the above factors could negatively influence the internal control quality. (d) Internal Control Environment. The outside factors on internal control quality include the auditor quality (big 4 firms or not) and the auditor's report (standard clean report or not); Meanwhile, the inside factors involve the firm's governance structure which can be measured by measuring Board of Directors' size. (e) Ownership Structure. Although private firms involve more and more business sectors, the SOEs are the major economic forces in most industries in China. The state ownership and the institutional environment have significantly related with the internal control quality (Liu Qiliang et al., 2012). State is the controllable variable for distinguishing the firm's ownership. All variables are demonstrated in the following Table 2.

Table 2. Variable definitions

\begin{tabular}{|c|c|c|}
\hline Variable & Description & Definition \\
\hline ICQ & Internal Control Quality & Internal control index (source DIB database) \\
\hline MgrlScore & Managerial Ability & The residual value $\varepsilon$ in equation 1 \\
\hline MgrlComp & Managerial Compensation & $\begin{array}{l}\text { The natural log of the top } 3 \text { executives compensation } \\
\text { (source CSMAR) }\end{array}$ \\
\hline LnAssets & Firm Size & $\begin{array}{l}\text { The natural log of the firm's total assets in year } t \text { (source } \\
\text { CSMAR) }\end{array}$ \\
\hline LnAge & Firm Age & $\begin{array}{l}\text { The natural } \log \text { of the number of years that the firm is } \\
\text { listed in the capital markets (source CSMAR) }\end{array}$ \\
\hline LnShare & Share equity & $\begin{array}{l}\text { The natural log of the sum of share capital and capital } \\
\text { reserve (premium) in year } \mathrm{t} \text { (source CSMAR) }\end{array}$ \\
\hline BusiComplesity & Business Complexity & $\begin{array}{l}\text { The proportion of non-current assets divided by total } \\
\text { assets (source CSMAR) }\end{array}$ \\
\hline Merge & Merger and Acquisition & $\begin{array}{l}\text { Dummy variable that sets equal to } 1 \text { if the number of } \\
\text { merger and acquisition is more than zero in year } t \text {, and } 0 \\
\text { otherwise (source CSMAR) }\end{array}$ \\
\hline ForeignTrans & Foreign Currency Translation & $\begin{array}{l}\text { Dummy variable that sets equal to } 1 \text { if there is foreign } \\
\text { currency translation in year } t \text {, and } 0 \text { otherwise (source } \\
\text { CSMAR) }\end{array}$ \\
\hline Loss & Net Loss & $\begin{array}{l}\text { Dummy variable that sets equal to } 1 \text { if the net income is } \\
\text { less than zero in year } t \text {, and o otherwise (source CSMAR) }\end{array}$ \\
\hline SalesGrowth & Sales Growth Rate & $\begin{array}{l}\text { Sales revenue in year } t \text { divided by sales revenue in year } \\
\mathrm{t}-1 \text {, then minus } 1 \text { (source CSMAR) }\end{array}$ \\
\hline Big4 & Big 4 Auditing & $\begin{array}{l}\text { Dummy variable that sets equal to } 1 \text { if the firm is audited } \\
\text { by the member of big } 4 \text {, and } 0 \text { otherwise (source CSMAR) }\end{array}$ \\
\hline AuditReport & Audit Report & $\begin{array}{l}\text { Dummy variable that sets equal to } 1 \text { if the audit result is } \\
\text { standard clean report, and } 0 \text { otherwise }\end{array}$ \\
\hline $\operatorname{LnBoD}$ & Board of Directors Size & $\begin{array}{l}\text { The natural log of the number of directors in Board of } \\
\text { Directors }\end{array}$ \\
\hline State & State Owned Enterprises & $\begin{array}{l}\text { Dummy variable set equal to } 1 \text { if the firm is SOE, and } 0 \\
\text { otherwise }\end{array}$ \\
\hline SalesSTD & Sales Volatility & $\begin{array}{l}\text { The standard deviation of sales divided by average assets } \\
\text { over the last } 5 \text { years }(2008-2012)\end{array}$ \\
\hline
\end{tabular}




\section{Aggression Model:}

$$
\begin{aligned}
& \text { ICQ }_{i t}=\alpha_{0}+\alpha_{1} \text { MgrlScore }_{i t}+\alpha_{2} \text { LnAssets }_{i t}++\alpha_{3} \text { LnAge }_{\text {it }}+\alpha_{4} \text { LnShare }_{i t}+\alpha_{5} \text { BusiComplexity }_{\text {it }}+\alpha_{6} \text { Merge } \\
& +\alpha_{7} \text { ForeignTrans }_{\text {it }}+\alpha_{8} \text { Loss }_{\text {it }}+\alpha_{9} \text { SalesGrowth }_{\text {it }}+\alpha_{10} \text { Big } 4_{\text {it }}+\alpha_{11} \text { AuditReport }+\alpha_{12} \operatorname{LnBoD}_{\text {it }}+\alpha_{13} \text { State } \\
& +\alpha_{14} \operatorname{SalesSTD}_{\mathrm{it}}+\varepsilon \\
& \mathrm{ICQ}_{\text {it }}=\alpha_{0}+\alpha_{1} \text { MgrlComp }_{\text {it }}+\alpha_{2} \text { LnAssets }_{\text {it }}++\alpha_{3} \text { LnAge }_{\text {it }}+\alpha_{4} \text { LnShare }_{\text {it }}+\alpha_{5} \text { BusiComplexity }_{\text {it }}+\alpha_{6} \text { Merge } \\
& +\alpha_{7} \text { ForeignTrans }_{\text {it }}+\alpha_{8} \text { Loss }_{\text {it }}+\alpha_{9} \text { SalesGrowth }_{\text {it }}+\alpha_{10} \text { Big }_{\text {it }}+\alpha_{11} \text { AuditReport }+\alpha_{12} \text { LnBoD }_{\text {it }}+\alpha_{13} \text { State } \\
& +\alpha_{14} \mathrm{SalesSTD}_{\mathrm{it}}+\varepsilon
\end{aligned}
$$

\section{Results}

\subsection{Descriptive Date and Correlation Analysis}

Table 3 demonstrates the descriptive analysis for this research and reflects the research sample data features. The Table 3 summaries the data information classified by the dependent variable (ICQ), the testable variable (MgrlScore and MgrlComp) and the control variables. There are totally 2,172 variable observes between 2009 and 2012. The sample data is a panel data. The dependent variable ICQ index on average is 672.2, while the minimum ICQ index is 0 and the maximum ICQ index is 981.8; the testable independent variable MgrlScore ranges from 0.00170 to 0.0285 . Its mean is 0.0164 which is similar as the median 0.0162; another testable variable MgrlComp averagely is 13.96 which is close to the median 14.00. The range of MgrlComp is from 10.40 to 16.45.

Table 3. Descriptive analysis

\begin{tabular}{lcccccc}
\hline Variable & $\mathrm{N}$ & mean & $\mathrm{sd}$ & $\min$ & median & $\max$ \\
\hline ICQ & 2172 & 672.2 & 142.2 & 0 & 693.8 & 981.8 \\
MgrlScore & 2172 & 0.0164 & 0.00433 & 0.00170 & 0.0162 & 0.0285 \\
MgrlComp & 2172 & 13.96 & 0.736 & 10.40 & 14.00 & 16.45 \\
lnAssets & 2172 & 21.84 & 1.145 & 18.16 & 21.76 & 26.06 \\
lnAge & 2172 & 2.260 & 0.641 & 0 & 2.485 & 3.091 \\
lnShare & 2172 & 20.60 & 0.860 & 18.79 & 20.55 & 24.14 \\
BusiComple $\sim$ y & 2172 & 0.256 & 0.177 & 0 & 0.222 & 0.971 \\
Merge & 2172 & 0.750 & 0.433 & 0 & 1 & 1 \\
ForeignTrans & 2172 & 0.314 & 0.464 & 0 & 0 & 1 \\
Loss & 2172 & 0.0792 & 0.270 & 0 & 0 & 1 \\
SalesGrowth & 2172 & 0.282 & 2.867 & -0.980 & 0.00481 & 110.1 \\
Big4 & 2172 & 0.0115 & 0.107 & 0 & 0 & 1 \\
AuditReport & 2172 & 0.971 & 0.167 & 0 & 1 & 1 \\
lnBoD & 2172 & 2.190 & 0.195 & 1.386 & 2.197 & 2.773 \\
State & 2172 & 0.583 & 0.493 & 0 & 1 & 1 \\
SalesSTD & 2172 & $1.420 \mathrm{e}+09$ & $3.550 \mathrm{e}+09$ & $2.244 \mathrm{e}+06$ & $3.910 \mathrm{e}+08$ & $3.710 \mathrm{e}+10$ \\
\hline
\end{tabular}

Table 4 shows the correlation between the dependent variable (ICQ) and the independent variable (MgrlScore and MgrlComp). The correlation among other variables are listed in the appendix. In Table 4, the correlation data 0.1738 means that ICQ and MgrlScore has a positive correlation which is statistically significant ( $p$-value $<0.01$ ). This result reflects that top executive's ability (MgrlScore) has related with internal control quality (ICQ); similarly, the correlation data 0.2935 in the column 2 also means that ICQ has correlated with MgrlComp in statistical significance (p-value $<0.01$ ). 
Table 4. Correlation between ICQ and MgrlScore and MgrlComp variables

\begin{tabular}{lccc}
\hline & ICQ & MgrlScore & MgrlComp \\
\hline ICQ & 1 & & \\
MgrlScore & $0.1738^{* * *}$ & 1 & \\
MgrlComp & $0.2935^{* * *}$ & -0.0296 & 1 \\
\hline significant at $10 \% ; * *$ significant at $5 \% ; * * *$ significant at $1 \%$ respectively
\end{tabular}

\subsection{Multivariate Regression Analysis}

Table 5. Managerial score and internal control quality

\begin{tabular}{|c|c|c|c|c|}
\hline & & (1) & (2) & (3) \\
\hline & & 2009-2012 & 2009-2011 & 2012 \\
\hline & Pred. Sign & ICQ & ICQ & ICQ \\
\hline MgrlScore & + & $\begin{array}{l}6,405.2215 \\
(8.2227)^{* * *}\end{array}$ & $\begin{array}{l}7,841.2355 \\
(8.1874) * * *\end{array}$ & $\begin{array}{l}-10,361.2855 \\
(0.6779)\end{array}$ \\
\hline lnAssets & + & $\begin{array}{l}40.5418 \\
(6.4554)^{* * *}\end{array}$ & $\begin{array}{l}41.2709 \\
(6.0649)^{* * *}\end{array}$ & $\begin{array}{l}54.7444 \\
(2.4583)^{* *}\end{array}$ \\
\hline $\ln A g e$ & $?$ & $\begin{array}{l}-16.4553 \\
(3.7026)^{* * *}\end{array}$ & $\begin{array}{l}-17.9618 \\
(3.9016)^{* * *}\end{array}$ & $\begin{array}{l}-21.2163 \\
(1.3264)\end{array}$ \\
\hline lnShare & + & $\begin{array}{l}-5.7303 \\
(0.8735)\end{array}$ & $\begin{array}{l}-4.5652 \\
(0.6375)\end{array}$ & $\begin{array}{l}-35.9545 \\
(1.1052)\end{array}$ \\
\hline BusiComplexity & - & $\begin{array}{l}70.3081 \\
(3.4452)^{* * *}\end{array}$ & $\begin{array}{l}80.0413 \\
(3.8712)^{* * *}\end{array}$ & $\begin{array}{l}-176.2800 \\
(0.6868)\end{array}$ \\
\hline Merge & - & $\begin{array}{l}-1.0503 \\
(0.1843)\end{array}$ & $\begin{array}{l}-1.4116 \\
(0.2162)\end{array}$ & $\begin{array}{l}-6.7631 \\
(0.5297)\end{array}$ \\
\hline ForeignTrans & - & $\begin{array}{l}8.5206 \\
(1.5087)\end{array}$ & $\begin{array}{l}9.4522 \\
(1.4927)\end{array}$ & $\begin{array}{l}-0.2864 \\
(0.0237)\end{array}$ \\
\hline loss & - & $\begin{array}{l}-183.7605 \\
(13.3499)^{* * *}\end{array}$ & $\begin{array}{l}-171.0683 \\
(10.6145)^{* * *}\end{array}$ & $\begin{array}{l}-223.4515 \\
(8.4965)^{* * *}\end{array}$ \\
\hline SalesGrowth & - & $\begin{array}{l}1.3112 \\
(3.4938)^{* * *}\end{array}$ & $\begin{array}{l}1.3239 \\
(3.7334)^{* * *}\end{array}$ & $\begin{array}{l}3.5422 \\
(1.5882)\end{array}$ \\
\hline Big4 & + & $\begin{array}{l}77.6601 \\
(2.9556)^{* * *}\end{array}$ & $\begin{array}{l}67.9757 \\
(2.4619)^{* *}\end{array}$ & $\begin{array}{l}121.6919 \\
(4.0861)^{* * *}\end{array}$ \\
\hline AuditReport & + & $\begin{array}{l}171.7895 \\
(5.6630)^{* * *}\end{array}$ & $\begin{array}{l}174.0068 \\
(5.6022)^{* * *}\end{array}$ & $\begin{array}{l}182.8819 \\
(2.6077)^{* * *}\end{array}$ \\
\hline $\ln B o D$ & + & $\begin{array}{l}32.4432 \\
(1.6951)^{*}\end{array}$ & $\begin{array}{l}38.8452 \\
(1.9407)^{*}\end{array}$ & $\begin{array}{l}3.3139 \\
(0.0850)\end{array}$ \\
\hline State & $?$ & $\begin{array}{l}-14.7854 \\
(2.2918)^{* *}\end{array}$ & $\begin{array}{l}-6.2543 \\
(0.8672)\end{array}$ & $\begin{array}{l}-32.0330 \\
(2.8676)^{* * *}\end{array}$ \\
\hline SalesSTD & - & $\begin{array}{l}0.0000 \\
(2.7417)^{* * *}\end{array}$ & $\begin{array}{l}0.0000 \\
(2.3600)^{* *}\end{array}$ & $\begin{array}{l}0.0000 \\
(2.8244)^{* * *}\end{array}$ \\
\hline Constant & & $\begin{array}{l}-402.1275 \\
(4.4473)^{* * *}\end{array}$ & $\begin{array}{l}-490.5187 \\
(5.0587)^{* * *}\end{array}$ & $\begin{array}{l}290.3597 \\
(0.6081)\end{array}$ \\
\hline Observations & & 2172 & 1629 & 543 \\
\hline Number of ID & & 543 & 543 & \\
\hline R-squared & & & & 0.3837 \\
\hline
\end{tabular}

Robust $\mathrm{z}$ statistics in parentheses

$*$ significant at $10 \%$;* significant at $5 \%$; ** significant at $1 \%$ 
The regression analysis based on model (2) includes 3 different sample groups. The $1^{\text {st }}$ sample groups cover the information from 2009 to 2012; the $2^{\text {nd }}$ sample groups cover the information from 2009 to 2011; the last comparative sample groups include the information in 2012. Before 2012, the internal control report is voluntarily disclosed. After 2012, all listed firms in China should report their internal control assessment results. The regression analysis is applying with statistics software STATA 12.1. The heteroscedasticity has already been considered during the regression analysis.

According to the Table 5, in the first regression model, the managerial ability is significantly associated with the internal control quality ( $\mathrm{p}$-value $<0.01$ ). Comparatively, in the $2^{\text {nd }}$ regression model, the managerial ability is still significantly related to the internal control quality ( $p$-value $<0.01)$. Interestingly, in the $3^{\text {rd }}$ regression model, there is no significant relationship between managerial ability and internal control quality. It means that with strictly regulation about internal control, the reported internal control assessment results cannot fully reflect the real internal control quality. The internal control quality could be inflated by the order and manipulation of top executives in the firms.

Table 6. Managerial compensation and internal control quality

\begin{tabular}{|c|c|c|c|c|}
\hline & & (1) & (2) & (3) \\
\hline & & $2009-2012$ & $2009-2011$ & 2012 \\
\hline & Pred. Sign & ICQ & ICQ & ICQ \\
\hline \multirow[t]{2}{*}{ MgrlComp } & + & 12.1589 & 9.6760 & 28.2256 \\
\hline & & $(2.8032)^{* * *}$ & $(1.9449)^{*}$ & $(3.4464)^{* * *}$ \\
\hline \multirow[t]{2}{*}{ lnAssets } & + & 41.1721 & 44.6932 & 33.1507 \\
\hline & & $(5.9156)^{* * *}$ & $(5.9365)^{* * *}$ & $(2.6641)^{* * *}$ \\
\hline \multirow[t]{2}{*}{$\ln A g e$} & $?$ & -23.1973 & -21.8948 & -25.4441 \\
\hline & & $(5.0027)^{* * *}$ & $(4.5456)^{* * *}$ & $(2.0570)^{* *}$ \\
\hline \multirow[t]{2}{*}{ lnShare } & + & -17.1416 & -18.8602 & -12.3222 \\
\hline & & $(2.4060)^{* *}$ & $(2.3961)^{* *}$ & $(0.9462)$ \\
\hline \multirow[t]{2}{*}{ BusiComplexity } & - & -34.4074 & -48.2016 & 2.2078 \\
\hline & & $(2.0986)^{* *}$ & $(2.7617)^{* * *}$ & $(0.0675)$ \\
\hline \multirow[t]{2}{*}{ Merge } & - & 1.5676 & 2.6347 & -9.5140 \\
\hline & & $(0.2710)$ & $(0.3996)$ & $(0.7552)$ \\
\hline \multirow[t]{2}{*}{ ForeignTrans } & - & 3.2199 & 3.3078 & -3.3471 \\
\hline & & $(0.5602)$ & $(0.5100)$ & $(0.2830)$ \\
\hline \multirow[t]{2}{*}{ loss } & - & -183.2069 & -169.8430 & -216.1532 \\
\hline & & $(12.7015)^{* * *}$ & $(9.7716)^{* * *}$ & $(8.3705)^{* * *}$ \\
\hline \multirow[t]{2}{*}{ SalesGrowth } & - & 1.2820 & 1.2551 & 3.7866 \\
\hline & & $(3.5102)^{* * *}$ & $(3.4462)^{* * *}$ & $(1.8624)^{*}$ \\
\hline \multirow[t]{2}{*}{ Big4 } & + & 74.7374 & 64.4507 & 107.9286 \\
\hline & & $(2.9918)^{* * *}$ & $(2.4119)^{* *}$ & $(3.6674)^{* * *}$ \\
\hline \multirow[t]{2}{*}{ AuditReport } & + & 170.5524 & 175.1241 & 182.0835 \\
\hline & & $(5.5196)^{* * *}$ & $(5.4507)^{* * *}$ & $(2.6869)^{* * *}$ \\
\hline \multirow[t]{2}{*}{$\ln B o D$} & + & 32.0859 & 37.2007 & 7.7393 \\
\hline & & $(1.6832)^{*}$ & $(1.8557)^{*}$ & $(0.1915)$ \\
\hline \multirow[t]{2}{*}{ State } & $?$ & -5.6674 & 1.7306 & -31.4605 \\
\hline & & $(0.8939)$ & $(0.2398)$ & $(2.8646)^{* * *}$ \\
\hline
\end{tabular}




\begin{tabular}{|c|c|c|c|c|}
\hline \multirow[t]{2}{*}{ SalesSTD } & - & 0.0000 & 0.0000 & 0.0000 \\
\hline & & $(3.4428)^{* * *}$ & $(3.0137)^{* * *}$ & $(2.9115)^{* * *}$ \\
\hline \multirow[t]{2}{*}{ Constant } & & -208.4199 & -232.5202 & -303.4849 \\
\hline & & $(2.5135)^{* *}$ & $(2.5417)^{* *}$ & $(1.8501)^{*}$ \\
\hline Observations & & 2172 & 1629 & 543 \\
\hline Number of ID & & 543 & 543 & \\
\hline R-squared & & & & 0.3958 \\
\hline
\end{tabular}

Robust $\mathrm{z}$ statistics in parentheses

* significant at $10 \% ; * *$ significant at $5 \% ; * * *$ significant at $1 \%$

In the Table 6, the regression analysis based on model (3) includes 3 different sample groups. The 1st sample groups cover the information from 2009 to 2012; the 2nd sample groups cover the information from 2009 to 2011; the last comparative sample groups include the information in 2012. This research uses top management's compensation as the alternative variable for measuring managerial ability. The regression result shows that the management ability (MgrlComp) is positively associated with the internal control quality from 2009 to 2012 (p-value $<0.01$ ). The regression model is statistically significant whenever the ICQ reporting period is voluntary ( $\mathrm{p}$-value $<0.1)$ or mandatory ( $\mathrm{p}$-value $<0.01$ ). Heteroscedasticity has already been dealt with during the regression analysis.

\section{Additional Analysis}

This research considers the MgrlScore and MgrlComp as the test variables respectively to find the significant relationship between the managerial ability and internal control quality. There are some other evidences to draw the similar conclusion. (a) The higher effective operation ability for the top management can be released by the financial motivation. Balsam et al. (2014) find that equity incentives granted to the top managements can strengthen the internal control quality over financial reporting. Then it is very logical that stronger managerial ability with equity motivation leads to higher quality of internal control. (b) Better reputation, higher respect and other non-financial rewards would encourage the top managements to supervise the firms with their more effective ability. However, the disclosure of internal control weakness would negatively influence their professional reputation and respective image. Ashbaugh-Skaife, et al. (2008) indicated that the firms which are reported the weaker of internal controls would even like to increase their accrual quality in line with the internal control quality. To keep good reputation, the top managements would also need demonstrate their stronger ability in internal controls. (c)There is evidence that the listed firms in China between 2010 and 2012 have less company-paid management consumption with stronger managerial ability (Zhang, et al., 2014; See Note 3). Less company-paid management consumption reflects the better quality of internal control.

Endogeneity may exist in the regression models of this research. The reasons for potential endogeneity may be due to some unobservable variables which can influence both ICQ and MgrlAbility, or the intersection relationship between ICQ and MgrlAbility. This research investigates the relationship between top executives working efficiency and the internal control quality in China's capital markets. However, the China's capital markets are different in the regulations and laws with other developed countries. The majority of listed firms in China's capital markets are SOEs. The governments whether in the central level or local level have much influences on the listed firms' operation. These impacts from the governments could be the tax policy, the market entry policy, the financing restrictions, the nomination and termination of top managers. Liu et al. (2012) find that the firms controlled by the central government have better internal control quality than the firms controlled by the local government in China. Meanwhile, the firms with more market-oriented business operation and less government interventions have better ICQ than others. In sum, the institutional environment has an impact on both the top manager's operation and internal controls. Therefore, some variables related to the institutional environment could make the research results biased. The endogeneity could be the limitation of this research. Further study can try to solve this potential endogeneity problem.

\section{Summary}

\subsection{Conclusions}

This research investigates the relationship between the managerial ability and internal control quality. DIB internal control index is applied as the dependent variable to measure the internal control quality. There are two proxies for 
measuring the managerial ability: MgrlScore, which reflects the top executives' efficiency based on the results of DEA analysis; MgrlComp, which represents the compensation of the top managers. With two regression models, these results both convinced that the top executives' ability has positively associated with the internal control quality. This result is statistically significant from 2009 - 2012. This research finds the relationship still exist within the voluntary ICQ reporting periods (2009-2011). However, when the MrglScore is the proxy of managerial ability, this significant relationship between managerial ability and internal control quality does not exist within the mandatory ICQ reporting periods (2012). When the MgrlComp is the proxy of managerial ability, this relationship is still statistically significant in all periods. All in all, it means that the strict mandatory ICQ reporting regulation could influence the internal control quality over financial reporting. The internal control quality could be inflated by the order and manipulation of top executives in the firms during the mandatory reporting period.

In additional analysis, this research explains that other evidences would also draw the similar conclusions in a conceptual way. The top managers' operation ability can be strengthen because of the financial and non-financial motivation. While, the equity incentives and reputation for the top executives have related with the internal control quality. Therefore, the managerial ability must relate to the internal control quality.

This research conclusion can benefit for some stakeholders of listed firms. Board of Directors can assess the top executives' performance (ability) partly based on the internal control quality of the firms; The investors and auditors can evaluate the listed firms' internal control quality according to the managerial ability; The firm's management also need to know that stronger managerial ability leads to better internal control quality, then lower cost of capital and higher shareholder's value.

\subsection{Limitations and Further Research Suggestions}

The potential endogeneity problem would be the limitation for this research. In this research, the data is based on the Shanghai and Shenzhen capital markets in China. The majority of listed firms in China's capital markets are giant companies and supported by the central or local government. The research result may not fit for the small size firms and private firms.

The capital markets' regulation required the listed firms to disclose their internal control quality just few years ago. The financial information about listed firm's internal control is scarce. The capital markets in China are still under developing stage. The institutional environment factors still have strong influences on the internal control quality. However, these factors would also make the research conclusion biased.

In the future research, researchers can continue to investigate how institutional environment and other political economic factors, such as the government economic policy influence on the internal control quality through the manager's behaviour. Also, with the time goes, more and more internal control information would be disclosed. Further researchers can use large size observables to find more accurate regression relationship.

\section{References}

Ashbaugh-Skaife, H., D.W. Collins, \& W.R. Kinney Jr. (2007). The discovery and reporting of internal control deficiencies prior to SOX-mandated audits. Journal of Accounting and Economics, 44, 166-192. http://dx.doi.org/10.1016/j.jacceco.2006.10.001

Ashbaugh-Skaife, H., D.W. Collins, W. Kinney, \& R. LaFond. (2008). The Effect of SOX Internal Control Deficiencies and Their Remediation on Accrual Quality. The Accounting Review, 83, 217-250.

Ashbaugh-Skaife, H., D. Veenman, \& D. Wangerin. (2013). Internal Control over Financial Reporting and Managerial Rent Extraction: Evidence from the Profitability of Insider Trading. Journal of Accounting and Economics, 55, 91-110. http://dx.doi.org/10.1016/j.jacceco.2012.07.005

Balsam, S., W. Jiang, \& B. Lu. (2014). Equity Incentives and Internal Control Weaknesses. Contemporary Accounting Research, 31, 178-201. http://dx.doi.org/10.1111/1911-3846.12018

Bamber, L., J. Jiang, \& I. Wang. (2010). What's My Style? The Influence of Top Managers on Voluntary Corporate Financial Disclosure. The Accounting Review, 85, 1131-1162. http://dx.doi.org/10.2308/accr.2010.85.4.1131

Bertrand, M., \& A. Schoar. (2003). Managing With Style: The Effect of Managers on Firm Policies. The Quarterly Journal of Economics, CXVIII(4), 1169-1208. http://dx.doi.org/10.1162/003355303322552775

Chen, H.W., \& Z.S. Zhou. (2014). Internal Control Quality and Corporate Bank Credit Loan Cost. Nankai Business Review (in Chinese), 17, 103-111. 
Cheng, M., D. Dhaliwal, \& Y. Zhang. (2013). Does investment efficiency improve after the disclosure of material weaknesses in internal control over financial reporting? Journal of Accounting and Economics, 56, 1-18. http://dx.doi.org/10.1016/j.jacceco.2013.03.001

Daily, C.M., \& Johnson, J.L. (1997). Sources of CEO Power and Firm Financial Performance: A Longitudinal Assessment. Journal of Management, 23(2), 97-117.

Dechow, P., R. Sloan, \& A. Sweeney. (1995). Detecting earnings management. The Accounting Review, 70, $193-225$.

Dechow, P., \& I. Dichev. (2002). The Quality of Accruals and Earnings: The Role of Accrual Estimation Errors. The Accounting Review, 77, 35-59.

Demerjian, P. R., B. Lev, M. F. Lewis, \& S.E. McVay. (2013). Managerial Ability and Earnings Quality. The Accounting Review, 88(2), 463-498. http://dx.doi.org/10.2308/accr-50318

Doyle, J., W. Ge, \& S. McVay. (2007a). Accruals quality and internal control over financial reporting. The Accounting Review, 82, 1141-1170.

Doyle, J., W.Ge, \& S. McVay. (2007b). Determinants of weaknesses in internal control over financial reporting. Journal of Accounting and Economics, 44, 193-223. http://dx.doi.org/ 10.1016/j.jacceco.2006.10.003

Feng, M., C.Li, \& S. McVay. (2009). Internal Control and Management Guidance. Journal of Accounting and Economics, 48, 190-209. http://dx.doi.org/10.1016/j.jacceco.2009.09.004

Finkelstein, S. (1992). Power in Top Management Teams: Dimensions, Measurement, and Validation. Academy of Management Journal, 35(3), 505-538. http://dx.doi.org/10.2307/256485

Garrett, J., R. Hoitash, \& D. Prawitt. (2014). Trust and Financial Reporting. Journal of Accounting Research, 52(5), 1087-1125.http://dx.doi.org/10.1111/1475-679X.12063

Goh, B.W., \& D. Li. (2011). Internal Controls and Conditional Conservatism. The Accounting Review, 86, $975-1005$. http://dx.doi.org/10.2308/accr.00000041

Hoitash, R., U. Hoitash, \& K.M. Johnstone. (2012). Internal Control Material Weaknesses and CFO Compensation. Contemporary Accounting Research, 29, 768-803. http://dx.doi.org/10.1111/j.1911-3846.2011.01122.x

Ji, X.D., W. Lu, \& W. Qu. (2015). Determinants and economic consequences of voluntary disclosure of internal control weaknesses in China. Journal of Contemporary Accounting \& Economics, 11(1). http://dx.doi.org/10.1016/j.jcae.2014.12.001

Jones, J. (1991). Earnings management during import relief investigations. Journal of Accounting Research, 29, 193-228

Kim, J., B. Song, \& L. Zhang. (2011). Internal Control Weakness and Bank Loan Contracting: Evidence from SOX Section 404 Disclosures. The Accounting Review, 86, 1157-1188.http://dx.doi.org/10.2308/accr-10036

Li, W. F., B. Lin, \& L. Song. (2011). The Role Played by the Internal Control in Companies' Investment: Is it a Promotion of Efficiency or a Repression thereof. Management World (in Chinese), 2, 84-99.

Lin, Y.C., Y.C. Wang, J.R. Chiou, \& H.W. Huang. (2014). CEO Characteristics and Internal Control Quality. Corporate Governance: An International Review, 22(1), 24-42.http://dx.doi.org/ 10.1111/corg.12042

Liu, Q.L., L. Luo, W.F. He, \& H.W. Chen. (2012). State Ownership, the Institutional Environment, and Internal Control Quality: Evidence from Chinese Listed Firms. Accounting Research (in Chinese), 3, 52-61.

Lu, R., J.H. Liu, \& N. Xu. (2011). Internal Control, Property Right and Executive Pay-Performance Sensitivity. Accounting Research (in Chinese), 10, 42-48.

Ogneva, M., K.R. Subramanyam, \& K. Raghunandan. (2007). Internal Control Weakness and Cost of Equity: Evidence from SOX Section 404 Disclosures. The Accounting Review, 82, 1255-1297.

Tian, G.L., B.L. Qi, \& L.C. Li. (2010). Determinants of the Discovery and Reporting of Internal Control Deficiencies over Financial Reporting. Nankai Business Review (in Chinese), 13, 134-141.

Tsay, B. Y. (2010). Designing an Internal Control Assessment Program Using COSO’s Guidance on Monitoring. The CPA Journal, 80, 52-57.

Xiao, H., \& G.Q. Zhang. (2013). Internal Control Quality, Earnings Persistence and Corporate Value. Accounting Research (in Chinese), 5, 73-80. 
Ye, J.F., D.M. Li, \& B.Y. Zhang. (2012). The Effect of Internal Control Deficiencies and Their Remediation on Earnings Management. Auditing Research (in Chinese), 6, 50-59.

Zhang, T.Z., \& M. Sha. (2014). Research on Managerial Ability, Power and Perks. Nankai Business Review (in Chinese), 17(5), 63-72.

\section{Notes}

Note 1. This database is operated by Hithink RoyalFlush Information Network Co.,Ltd. The database can supply financial information, such as stock, bond, mutual funds and other major financial information in Chinese financial markets. The wetsite is: www.10jqka.com.cn

Note 2. DEAP 2.1 is a computer based program. More information can be found in the working paper: A Guide to DEAP Version 2.1: A Data Envelopment Analysis (Computer) Program, Coelli T.J., CEPA working papers, Department of Econometrics, University of New England, Armidale, NSW 2351, Australia. http://www.une.edu.au/econometrics/cepawp.htm

Note 3. In the research of Zhang. et al.(2014), the managerial ability is also measured by the DEA method. The company-paid management consumption mainly refers to the consumption which benefits for the managements private interests is charged as the firms' administration expenses.

\section{APPENDIX}

Appendix 1. Correlation matrix

$(\mathrm{obs}=2172)$

\begin{tabular}{|c|c|c|c|c|c|c|c|c|c|c|c|c|c|c|c|c|}
\hline & ICQ & MgrlScore & MgrlComp & $\ln$ Assets & $\ln A g e$ & lnShare & BusiComplxity & Merge & ForeignTrans & loss & SalesGrowth & Big4 & AuditReport & $\operatorname{lnBoD}$ & State & SalesSTD \\
\hline ICQ & 1 & & & & & & & & & & & & & & & \\
\hline MgrlScore & 0.174 & 1 & & & & & & & & & & & & & & \\
\hline MgrlComp & 0.293 & -0.0296 & 1 & & & & & & & & & & & & & \\
\hline lnAssets & 0.366 & -0.0573 & 0.399 & 1 & & & & & & & & & & & & \\
\hline $\ln A g e$ & -0.0579 & -0.104 & 0.0682 & 0.309 & 1 & & & & & & & & & & & \\
\hline lnShare & 0.223 & -0.201 & 0.305 & 0.833 & 0.303 & 1 & & & & & & & & & & \\
\hline BusiComplexity & y -0.111 & -0.694 & -0.142 & -0.0217 & 0.0164 & 0.0298 & 1 & & & & & & & & & \\
\hline Merge & 0.0517 & 0.117 & 0.0748 & 0.0733 & 0.0232 & 0.0478 & -0.110 & 1 & & & & & & & & \\
\hline ForeignTrans & 0.113 & 0.0379 & 0.197 & 0.114 & -0.072 & 0.0803 & -0.118 & 0.0211 & 1 & & & & & & & \\
\hline loss & -0.477 & -0.0991 & -0.201 & -0.0935 & 0.0799 & -0.032 & 0.117 & -0.0634 & -0.0551 & 1 & & & & & & \\
\hline SalesGrowth & 0.00120 & -0.0561 & -0.00110 & -0.0239 & 0.0279 & 0.0165 & 0.0698 & -0.0058 & -0.00650 & -0.022 & 1 & & & & & \\
\hline Big4 & 0.0725 & -0.00280 & 0.0886 & 0.0857 & 0.0721 & 0.0648 & -0.00520 & 0.00240 & 0.0665 & -0.016 & -0.00700 & 1 & & & & \\
\hline AuditReport & 0.372 & 0.0349 & 0.142 & 0.206 & -0.075 & 0.0511 & -0.0131 & -0.0094 & 0.0564 & -0.226 & -0.115 & -0.059 & 1 & & & \\
\hline $\ln B o D$ & 0.0810 & -0.104 & 0.0855 & 0.250 & 0.120 & 0.236 & 0.115 & 0.00790 & -0.0280 & 0.0324 & 0.000800 & -0.001 & 0.00640 & 1 & & \\
\hline State & -0.0077 & -0.0728 & 0.00710 & 0.266 & 0.416 & 0.247 & 0.163 & -0.0347 & -0.0694 & 0.0579 & 0.0268 & 0.0563 & 0.00640 & 0.180 & 1 & \\
\hline SalesSTD & 0.238 & 0.0464 & 0.177 & 0.503 & 0.121 & 0.397 & -0.0439 & 0.0354 & 0.147 & -0.056 & 0.0498 & 0.0180 & 0.0522 & 0.0833 & 0.126 & 1 \\
\hline
\end{tabular}

